\title{
Readiness and Challenges of Counsellor in Offering Gerontological Counselling in Malaysia
}

\author{
Haikal Anuar Adnan, Khadijah Alavi*, Amran Hassan, Daniella Maryam Mokhtar \\ Faculty of Social Sciences and Humanities, The National University of Malaysia, Bangi, Malaysia \\ Email: ^khadijah@ukm.edu.my
}

How to cite this paper: Adnan, H. A., Alavi, K., Hassan, A., \& Mokhtar, D. M. (2020). Readiness and Challenges of Counsellor in Offering Gerontological Counselling in Malaysia. Creative Education, 11, 2580-2593.

https://doi.org/10.4236/ce.2020.1112190

Received: September 25, 2020

Accepted: December 8, 2020

Published: December 11, 2020

Copyright (c) 2020 by author(s) and Scientific Research Publishing Inc. This work is licensed under the Creative Commons Attribution International License (CC BY 4.0).

http://creativecommons.org/licenses/by/4.0/

\begin{abstract}
Malaysia is expected to become an old age nation by 2030. The psychological problem faced by elderly requires counselling intervention. The objective of this study is to explore the readiness of counsellors in dealing with adult and aging as curriculum and to explore the challenges in providing gerontological counselling. The study was used qualitative approach based on case study of 9 informants on purporsive sampling method and conducted within indepth interviews. The findings showed that level of readiness of counsellor is very high and very interested to dealing with aging client. The main challenges of counselor are no public universities offer courses gerontological counselling in Malaysia. The implication of this study involvement of gerontological counsellor through Malaysian Association of counsellor will attract young counsellor interest in the care of older person.
\end{abstract}

\section{Keywords}

Counselling, Gerontology, Challenge, Readiness

\section{Introduction}

Malaysia is expected to follow the global trend of ageing population. Based on the projected population, Malaysia is expected to be an aged country (aged nation) by 2035 when the percentage of senior citizens aged 60 years and above reaches $15 \%$ of the total. According to the Department of Statistics Malaysia in 2015 and Talha (2015), life expectancy for senior women and men in Malaysia is 77.4 years and 72.5 years respectively and by 2020 , it will increase to 80.4 years and 75.4 years respectively (Salleh, 2016). The aging phase poses various problems to the elderly or their caregivers. Deteriorating physical health can cause a variety of mental and emotional problems for the elderly. Mobility or movement of the elderly will also decline until the elderly are somewhat isolated from so- 
ciety. The aging process can lead to various physical, mental changes and the ability to act and move. Elderly people with health problems such as dementia, disability and chronic diseases are said to be at higher risk of abuse and neglect compared to healthy and productive senior citizens (Abdul Aziz Jemain et al., 2001; Wan Ahmad et al., 2009; Endut, \& Ahmad, 2009; Bakar et al., 2009; Khadijah \& Rahim, 2010; Dong, 2015). According to Tanaka et al. (2015) on average senior citizens with severe dementia will also experience depression. While Tay et al. (2018) and Sharif et al. (2019) found that people with dementia often face depression, anxiety and confusion that make it difficult to carry out daily activities as usual. Even anxiety and depression occur simultaneously among dementia patients where 20 to 40 percent of patients are prone to anger. So mental health is the most complex problem among health disorders compared to diabetes, heart disease, high blood pressure, arthritis and more.

In addition, the scenario of abuse and neglect of senior citizens in Malaysia is considered as an issue that is hidden from public knowledge and even among social issues that are marginalized in society (Abdul Aziz, 2001; Manaf, 2002; Esther, Shahrul, \& Low, 2006). According to the study of Jamaluddin et al. (2017), 1 in 20 senior citizens in Malaysia were found to have been intentionally or unintentionally abused by family members as well as people who are closely related to senior citizens. Therefore, this issue or problem is not seen as a worrying problem because the abuse situation that occurs is within the confidentiality of the victims of abuse and perpetrators (Mohd Yusoff, 2009, 2010). The problem of neglect of elderly patients also fails to be detected due to lack of understanding and knowledge of the community, especially among healthcare professionals (Esther, Shahrul, \& Low, 2006). Past studies in Malaysia that focus on the issue of neglected elderly patients still have room to expand to examine various aspects related to neglect and care of the elderly. This is because one of the hot issues that are the main debate today is about the neglect of the elderly and their placement in care centers whether in the government, NGO or paid sector (Sharif et al., 2015 and Bidin \& Mohd Yusoff, 2015). The study of Mansor et al. (2019) found that the majority of senior caregivers have ever committed one form of neglect of the elderly in the care center for the elderly in Malaysia. This problem of abuse and neglect indirectly impairs the mental health of the elderly. However, senior citizens who face various problems can be helped through counselling services in the community.

Counselling services in Malaysia were introduced in the 40s (Lloyd \& Hashim, 1987) and were then formally introduced in 1963 certificate level courses at the College of Special Education, Cheras, Kuala Lumpur. Following that, in 1981 undergraduate counselling courses were offered at Universiti Pertanian Malaysia, then in 1989, Universiti Kebangsaan Malaysia offered a diploma in psychology (Counselling). Meanwhile, in 1984, several other public universities began to offer courses at undergraduate and graduate levels. The main goal of this counselling guidance education is to train and provide prospective counsellors supplied 
in all service sectors in Malaysia (Abu \& Othman, 2009). The main focus of providing counselling services refers to helping services in various cultural and community contacts. Furthermore Abu \& Othman (2009) commented that services focused on consulting services such as financial consulting services, academic consulting, financial consulting services, career consulting, group consulting/ psychotherapy, drug use eradication services, testing services, measurement and evaluation, interview techniques and community service. However, problems related to the well-being of the elderly and their caregivers have not received attention in offering educational curriculum and counselling guidance at any public universities in Malaysia.

Previous studies related to the challenges of counsellors in dealing with clients in various settings have been done by several previous researchers. Among the studies on the challenges of counsellors that are widely conducted are in school settings (Boitt, 2016; Egbo, 2015; Anagbogu et al., 2013; Mushaandja et al., 2013; Nyamwange et al., 2012; Johari Talib, 2009). For the study of counselling for the elderly, it was found that most of the studies conducted were to see the effectiveness and importance of counselling sessions in helping (Ogedegbe et al., 2013; Demirdis \& Celik, 2013; Carmen, 2013; Rantanen et al., 2019; Rantanen et al., 2020), the effects of chronic illness on counselling sessions (Visser, 2000) and the need for guidance and counselling for the elderly (Demirdis, 2013). However, specific studies to study the readiness and challenges faced by counsellors in dealing with counselling with senior citizens are still lacking in Malaysia. This is in line with the opinion of Nurul Hudani Nawi et al., (2016) who stated that studies on psychology and counselling for the elderly need to be conducted more widely. One of the least discussed or conducted aspects of previous studies is the preparation of counsellors in taking steps to offer community counselling services to reduce anxiety among the elderly and their caregivers. Therefore, counsellors need to be competent in requiring the preparation of specialized counselling knowledge, theory and skills in the field of gerontology or geriatrics to deal with clients with mental, physical, emotional and psychosocial health problems among the elderly and their caregivers. Counselling services can help improve the well-being and quality of life of the elderly. Negative stereotypes about the treatability of older people and a lack of psychotherapy theory that can speak to later life still have a pervasive negative effect on expectations and expertise (Hepple, 2004).

\section{Research Objectives}

The main objective of this article is to explore the preparation and challenges of counsellors in offering gerontological counselling services in Malaysia.

\section{Method}

Qualitative design can guide the researcher with ensuring that the research questions and objectives are met in which a case study approach was used. Case study is a form of research on social issues or phenomena that occur in society that is 
explored through one case or a variety of cases (Yin, 1994; Creswell, 2009). The case study approach that was conducted is inductive via in-depth interviewing of qualitative research informants. Purposive sampling was used to recruit counsellors who have between 3 to 15 years of experience and are registered with the Board of Counsellors (Malaysia) with a valid practice certificate. This cross-sectional study involved 9 informants who agreed to be interviewed. Researchers used online interview methods such as email, facebook (FB) and telephone. Royse (2011) defines purposive sampling as a sampling procedure on a group of subjects with specific characteristics that fits the researcher's specific objectives.

Analysis was carried out using the Manual Qualitative Analysis (MQA) to obtain the results of the study (Seidel, 1998). The qualitative analysis method is best used in this study because non-processed information via computer can be treated as additional information to complement the research objective. This qualitative data analysis method is also used to better understand some of the issues that require verbal explanations of informants. Patton (1990) \& Moleong (2002) stated that data analysis is the process of organizing data, organizing it into a patterns and description. Analysis is the process of solving topics into component components and understanding how the components fit into each other (Hammond \& Wellington, 2013). In this study, the researcher used thematic analysis which are defined themes found in the study taken from interview transcripts and interpreted data to present the data.

\section{Demographic Profile of the Informants}

The demographic profiles of the informants include gender, age, education, length of service and career in counselling. The informants of this study were between 29 and 40 years old. The study found that almost all informants had a bachelor's degree in education and their counselling experience were between 3 and 15 years. This indicates that the informants have sufficient experience in the field of counselling. In terms of career selection, it also varied between 5 working faculty in Public Universities and Private Universities; 2 people in Public Service Department (JPA); a psychologist and a freelance counsellor.

\section{Counsellors' Challenges in Providing Services to Elderly Clients}

The findings show that the majority of counsellors find expertise in the field of gerontological counselling has not been offered in Malaysia. According to Informant 1, no access to expertise is required in the field of senior citizens. Exposure to training and courses that are more focused on gerontological counselling is essential in preparation for reaching an aging country. Malaysia has 10 years to deal with the tsunami of senior citizens. However, the statement of informant 2 found that "1) No further topics in the field of gerontology counselling at the Public University (bachelor's \& master's degrees); 2) It is possible that many counsellors have no knowledge of gerontology counselling, 3) Senior clients don't 
like to come to counselling sessions based on my experience where they would rather spend their own time at home and 4 . The need to get counselling is unnecessary (Informant 2). Lack of expertise and skills in gerontology counselling also create anxiety in conducting sessions with senior client counselling. The informant's statement said that senior clients do not like to attend counselling sessions and that they prefer to live alone at home and feel that there is no need for counselling sessions to be an assumption or stereotype for senior citizens. The provision of counselling services for senior citizens over the next 10 years is likely to be different from that of today's senior citizens. Education and exposure to counselling needs has also increased.

From the data obtained, informants 4, 5, 8 and 9 stated that it should be the basic requirements for knowledge in this field of gerontology. This is because, most of them focus on the areas of family counselling, marriage, and children. Similar to psychology, there is no element that focuses on the field of gerontology more fully. More emphasized aspects include clinical, developmental and organizational. The current psychologist/Counsellor Officer lacks knowledge in the field of senior citizens, in addition to conducting better counselling sessions with senior citizens therapeutically. Lack of knowledge in this field has led to the psychologists/Counsellor Officers stalling to conduct counselling with senior citizens. In fact, what is noticeable in this group of senior citizens is the use of their skills in listening and giving feedback that forms the basis for all the problems that arise within the client's senior citizen. This failure in listening and treating skills has led to poor counselling sessions in understanding senior citizens.

The main challenge is to develop the interest and patience to serve the elderly. Without special training people who work with senior citizens are under stress. Furthermore, the references and training related to senior citizens are less emphasized in this country. The field of developmental psychology in the country also only emphasizes early childhood and adolescent education. (Informant 4)

Among the challenges of working exclusively with senior citizens is the lack of knowledge and knowledge about gerontology. This will be a bit of a gap in the delivery of effective counselling and psychological services. (Informants 5 )

The challenge I see is the expertise within each of the officers assigned to work with senior citizens. Not only without high passion, but without the knowledge of managing issues related to senior citizens, of course those tasks and services would be problematic and would disrupt the system and quality of service and undermine this helping profession. (Informants 8)

Lack of exposure and specialized developmental knowledge of senior citizens and special counselling skills to assist senior citizens. (Informant 9)

In addition, according to Informant 7 is the preparation of training among psychologists/Counsellor Officers on counselling of senior citizens. Existing training is more focused on Gerontological training alone, and not on counselling for senior citizens. Among the trainings that can be included is understanding the elderlies in the context of psychology, senior counselling skills, physical, emotional, mental and psychological care, coping skills among senior citizens and 
preparation of appropriate psychological tests in looking at senior citizens' specificities. In fact, these elements seem to have been ignored in the sense that assuming senior citizens do not need counselling. The disparities in senior citizens within the care center compared to those outside the context of counselling are needed. In fact, there have been some previous studies that found that older people in care centers need more counselling sessions than older people outside care centers. This is because they need the attention, attention and love from their family members so much that they fall sick from missing their children and relatives. This is the basic training that a psychologist or counsellor needs to help understand seniors more specifically. All of these are compulsory elements when it comes to the counselling process of senior citizens in helping to better their daily lives.

The challenge is the underdeveloped syllabus or courses on gerontological counselling. To this day, there is not a single branch dedicated to counsellors interested in gerontology. As such, skills and knowledge in this field are very limited. This can have a negative impact if the counsellor does not have enough resources to deal with the elderly. (Informant 7 )

Similar to the element of emotion management based on Informant 6, this understanding is broad and comprehensive. The emotions of these seniors change from time to time and according to their mood. Emotional downturns are a normal thing. This is because they will return to the phase that requires attention and affection just as in our childhood phase. They need the attention to rationalize their thinking that would the fit the norm based on their age. This is what they want, not something more than that. In fact, the role of these emotions is so great that if left unfulfilled it will lead to depression. Depression can also lead to mental health issues among the elderly if left unchecked. There is a sense of loneliness, crying, moaning, intense longing for a husband, wife or children, being silent, and sometimes speaking alone (monologue/interior monologue), and isolation. It has a profound effect on the minds and minds of the elderly who are not psychologically assisted. In fact, this can lead to mental illness. Such emotional care can bring an important element to help conduct counselling sessions with senior citizens and achieve exciting levels.

The challenge lies in managing the emotions of the elderly and also affecting their physical abilities. (Informant 6)

Finally, based on Informant 3 is the psychologist or counsellor's own ability to treat these senior citizens. Most of the elderlies do not hear, do not want to talk, are sick and do not want to share. These are some of the obstacles that a psychologist or counsellor will have to deal with. Patience with the elderly is a key element that psychologists or counsellors need to have. In fact, a counsellor is expected to accept clients unconditionally including senior citizens who need counselling. Old age is what everyone will face one day. Therefore, having illness, in ability to hear properly, refusing to talk and the lack of cooperation are things that should be expected. As such, the expertise and attitude of the psy- 
chologist or counsellor is crucial in dealing with such cases that will help to make the counselling session more successful. This is said to be a challenge for a psychologist or counsellor in a counselling session with senior citizens.

The main challenge is in terms of interest, the ability of the counsellor him/ herself as the senior citizen likes a counsellor or anyone who hears them speak. In addition, the difficulty the face in concentrating, hearing problems and poor memory at the time (informants 3 )

\section{Discussion}

The findings show that there are three key themes that counsellors face in dealing with the issue of gerontology counselling, which is the lack of expertise in the field of gerontology counselling, lack of interest and skills in providing services to senior citizens and elderly clients avoiding attending sessions and with limited psychological capacity.

\subsection{Challenges in Terms of Lack of Expertise}

According to Abeysekera (2020), expertise can be defined as the internal characteristics of an individual. Individuals with expertise allow them to do something efficiently. Besides that, expertise can be acquired through either formal or informal learning. In the context of the counsellor's expertise, the requirements for counselling programs by institutions of higher learning are important because in order for an individual to be eligible to apply as a registered counsellor, they must meet the minimum requirements for a bachelor's or master's degree from an institution recognized by the Malaysian Board of Counsellors (Malaysia Counsellors Act, 1998). The findings of this study are in line with the findings of Fullen (2018) who stated that students' lack of interest in gerontological counselling services was due to the lack of specialized program offerings in the field of gerontology counselling as well as the lack of usable facilities. Lack of expertise in gerontology counselling can be seen through programs offered by the Malaysian Institute of Higher Learning in which there are 10 IPTAs offering undergraduate counselling programs namely UPM, UPSI, UM, UIAM, UUM, USIM, UMS, UMT, UNIMAS and UNISZA. However, all these institutions offer only a Bachelor of Counselling program at the core and have no specialization in specific settings. For the Bachelor of Counselling program, there are $11 \mathrm{HEI}$ that offer undergraduate and only USIM programs that specialize in family counselling and drug abuse.

Offering specific programs in the field of gerontological counselling is essential as Malaysia is moving towards become and advanced country. In addition, the issues faced by older people that varies from the abuse and neglect of older people with chronic illness (Abdul Aziz Jemain et al., 2001; Wan Ahmad et al., 2009; Endut \& Ahmad, 2009; Bakar et al., 2009; Khadijah \& Rahim 2010; Dong, 2015), dementia disease that leads to depression (Tanaka et al., 2015; Tay et al., 2018; Sharif et al., 2019), marginalized in community groups (Abdul Aziz, 2001; 
Manaf, 2002; Esther, Shahrul, \& Low, 2006) and the accidental abuse of family members or close relatives (Jamaluddin et al., 2017) also demanded programs specific in the field of gerontology. This is also supported by the Malaysia Department of Higher Education (2011) which recommends that each HEIs offering undergraduate degree programs should consider offering a specialized program of study in line with the existing expertise and demands of current holders. In this regard, the absence of specialized program offerings in the field of gerontology counselling is seen as one of the main challenges faced by counsellors as the Institution of Higher Education is a knowledge-based institution providing the knowledge and skills needed to serve senior citizens.

\subsection{Challenges from the Aspect of the Counsellor}

The findings show that counsellors may also pose as one of the challenges in conducting counselling sessions involving senior citizens. These counsellor factors include a lack of interest as well as a limitation on the skills of the counsellor. In terms of interest, the findings of this study are in line with the findings of a study conducted by Rozaino \& Fuad Mohd Kari (2018) which found that young counsellors and undergraduate students have less favorable views on senior counselling. However, this finding is not consistent with the findings of Foster, Kreider, \& Waugh (2009) who found that most students are interested in working in gerontology settings such as hospice setting, hospital geriatric unit, nursing home, private practice with older adults, counselling counselling and community setting with older adults. In addition, their research also shows counselling students are interested in topics related to gerontological counselling such as grief counselling, retirement counselling, family counselling with senior citizens and senior caregiving counselling. According to the Social Cognitive Development Model (Brown \& Lent, 1996), an individual's interest in a career depends on how well an individual perceives themselves to be doing something and their expectations on it are positive or negative. If the expectations are positive, they are more likely to pursue that interest compared to when their expectations are negative. Accordingly, students' interests or gerontological counsellors will depend on their expectations of their ability and skills in performing gerontological counselling services. Therefore, one of the important roles of institutions of higher learning is to provide opportunities for counsellors to acquire expertise and skills as existing skills can increase the interest of the elderly (Alavi et al., 2019b).

In addition, the findings of this study are also in line with the findings of a study conducted by Nikumaa \& Leinonen (2019) who found that counsellors' challenges facing older people with dementia were lack of knowledge and skills so that counsellors sometimes failed to provide full information due to their reluctance to provide accurate information. In addition to the basic counselling skills that can be learned while studying at a tertiary institution, there are a number of specific skills that are needed in conducting counselling services with senior citizens. According to Ismail et al. (2007), some of the basic skills that are 
not appropriate when using counselling services are confrontational while what a counsellor should do is encourage senior citizens to tell stories. Other skills needed in a gerontological counsellor are physical activity counselling as it can improve the mood of older people with minor depressive symptoms (Pakkala et al., 2008); the strategy of religious intervention for maintaining the well-being of the world and the hereafter (Ismail \& Wan Ahmad, 2006); a combination of counselling and exercise to improve physical and cognitive health (Brovold et al., 2012); Reminiscence Therapy as it is found to be effective in helping to improve psychological well-being (Alavi et al., 2019a); Lifestyle counselling as it helps reduce hypertension of older people (Ogedebe et al., 2013); Yoga Therapy (Anyanwu et al., 2019); integrated of animal-assisted therapy and elderly play therapy (Kil, Yoon, Ryu, \& Kim, 2019) and family counselling need to be done before senior citizens are placed in institutions to prevent misunderstandings (Carmen, 2013). All these counselling strategies and therapy was proven in enhancing the physical and psychological problem among older people. These specialized skills are rarely acquired through courses or subjects of counselling that are of the essence and are seen as one of the challenges that counsellors face in serving senior citizens.

\subsection{Challenges from the Aspect of the Elderly}

Among the challenges of the elderly are the physical and psychological factors of senior citizens in counselling sessions. Counselling sessions are a two-way professional assisting process that involves both counsellors and clients. In the context of gerontological counselling, clients to counsellors are senior citizens. Aging is seen to affect cognitive, physical and psychological functioning. According to Corey \& Corey (2002) and Toner \& Shadden (2002), the ability of senior citizens to focus on discussions during sessions is one of the challenges in conducting counselling services to senior citizens. The maximum focus of the client is important in the counselling session because if the client is not able to fully focus on what is being discussed, the client is likely to be unable to fully engage in the planning with the counsellor. Therefore, the effectiveness of counselling sessions cannot be optimized. Older adults are also more likely to experience memory problems as well as the effects of medications taken to affect their cognitive function. Apart from physical and psychological issues, senior citizens are also seen as less interested in conducting counselling sessions. This is evidenced by the findings from Demirdis's (2013) study that found that most retired seniors from around the world are not interested in conducting counselling sessions with counsellors. This may be because awareness of senior counselling services is not yet high. In addition, older people are more likely to talk and share feelings with family members especially children and spouses than with outsiders (Alavi et al., 2019b). However, for older people living in care centers and hospitals it is apparent that they have a high demand for counselling services (Hill \& Brettle, 2004). This may be because older people in the care center do not have close in- 
dividuals to share their feelings and problems while in the hospital setting, counselling services on health issues are needed.

\section{Conclusion}

Counsellor still faces many challenges in providing gerontological counselling services to elderly clients at community, hospital and care centers. The main challenges are knowledge and skills in dealing with senior citizens with chronic illnesses such as dementia, alzeimers, heart patients, diabetes and hypertension. As a result of these various physical illnesses, it affects the mental, emotional and psychological health of the elderly. This study can provide exposure to counsellors to prepare themselves with knowledge and skills necessary in gerontological counselling. They need to find initiatives to acquire these knowledge and skills through workshops or courses organized by relevant parties either locally or abroad. Furthermore, no public university offers postgraduate and postgraduate courses in gerontology counselling in Malaysia to provide such services in hospitals and care centers. Public or private institutions of higher learning may also begin to offer gerontology counselling courses to enhance counsellors specific competencies. This is because counsellors need to be competent to prepare for senior clients in counselling sessions. The increasing density of senior citizens needs to be in line with the gerontological counselling services offered at all public universities to address the issues and concerns of seniors and their caregivers. Even the job market in the field of gerontology counselling is also vastly underdeveloped in Malaysia especially providing services to those in need especially in the scenario of bereavement, palliative care and acute disease condition. For example, the COVID-19 phenomenon of death among senior citizens is so high that families cannot honor their parents' funeral. This situation can lead to chronic depression in children who find it very tragic and heart breaking.

\section{Acknowledgements}

This study was fully funded by Small Research Grant: SK-2019-011, Faculty of Social Sciences and Humanities, Universiti Kebangsaan Malaysia. Acknowledgments are also addressed to all who have been participated in this study especially counsellors and all the informants.

\section{Conflicts of Interest}

The authors declare no conflicts of interest regarding the publication of this paper.

\section{References}

Abdul Aziz, R. (2001). Perubahan Populasi Warga Tua, Perkhidmatan Penjagaan dan Implikasi Dasar. In A. A. Jemain, L. Z. Mohamad, \& W. N. Mohamed (Eds.), Jaminan Sosial Warga Tua (pp. 11-22). Selangor: Prentice Hall.

Abeysekera, R. (2020). Examining Counsellor Expertise: Evidence from the Sri Lankan 
Microfinance Sector. Business Ethics and Leadership, 4, 57-67. https://doi.org/10.21272/bel.4(1).57-67.2020

Abu, T., \& Othman, A. H. (2009). Kaunseling untuk kesejahteraaan: Satu kajian kes perkhidmatan kaunseling di UKM. Jurnal Personalia Pelajar, 12, 1-17.

Alavi, K., Fauze, N., Md. Akhir, N., \& Hasan, N. (2019a). Meneroka Kompetensi Kerja Sosial Gerontologi: Persediaan Pelajar dalam Bidang Penjagaan Warga Emas di Malaysia. Proceedings of the MASW-JKM-ISM International Social Work Symposium 2019, Kuala Lumpur.

Alavi, K., Hazlan, N. H., \& Fauze, N. (2019b). Industrial Training Focused on Vocational Senior Citizen Care in Gerotological Social Work Course, FSSK UKM. Journal Ajtlhe, 11, 48-58.

Alavi, K., Sharif, N. C., \& Subramaniam, P. (2019c). Hubungan antara Kebimbangan dan Kemurungan dengan Kualiti Hidup Warga Emas Demen sia: Keperluan Terapi Kenangan Berkelompok di Institusi Penjagaan. Universiti Mal aysia Terengganu Journal of Undergraduate Research, 1, 95-104.

Anagbogu, M. A., Nwokolo, C. N., Anyamene, A. N., Anyachebelu, F. E., \& Umezulike, R. Q. (2013). Profesional Challenges to Counselling Practice in Primary Schools in Anambra State, Nigeria: The Way Forward. International Journal of Psychology and Counselling, 5, 97-103.

Anyanwu, J. I., Ngwoke, O. R., Victor-Aigbodion, V., Nnamani, O., \& Nwefuru, B. C. (2019). Effect of Yoga Therapy on Low Back Pain Management among Older Adults: Implications for Gerontology Counselling. Global Journal of Health Science, 11, 1-17. https://doi.org/10.5539/gjhs.v11n8p1

Bakar, N. A., Idris, N. A. H., \& Selvaratnam, D. P. (2009). Kesejahteraan ekonomi warga emas di Malaysia: Perbezaan gender. Persidangan Kebangsaan Ekonomi Malaysia ke-IV 2009-Memacu pembangunan ekonomi dalam ketidaktentuan persekitaran global, De Rhu Beach, 2-4 June 2009.

Bidin, A., \& Mohd Yusoff, J. Z. (2015). Experience of Domestic Abuse among Malaysian Eld erly. Pertanika Journal Social Sciences \& Humanities, 23, 107-118.

Boitt, M. L. J. (2016). Evaluation of the Challenges in the Implementation of the Guidance and Counselling Programme in Baringo County Secondary Schools, Kenya. Journal of Education and Practice, 7, 27-34.

Brovold, T., Skelton, D. A., \& Bergland, A. (2012). The Efficacy of Counselling and Progressive Resistance Home-Exercises on Adherence, Health-Related Quality of Life and Function after Discharge from a Geriatric Day-Hospital. Archives of Gerontology and Geriatrics, 55, 453-459. https://doi.org/10.1016/j.archger.2012.01.015

Brown, S. D., \& Lent, R. W. (1996). A Social Cognitive Framework for Career Choice Counselling. The Career Development Quarterly, 44, 354-366. https://doi.org/10.1002/j.2161-0045.1996.tb00451.x

Carmen, S. M. (2013). Importance of Counselling for Elderly before Institutionalization. Procedia-Social and Behavioral Sciences, 84, 1630-1633. https://doi.org/10.1016/j.sbspro.2013.07.004

Corey, M. S., \& Corey, G. (2002). Groups, Process and Practice. Monterey, CA: Brooks/ Cole.

Creswell, J. W. (2009). Research Design: Qualitative, Quantitative, and Mixed Methods Approaches (3rd ed.). Thousand Oaks, CA: Sage Publications.

Demirdis, E. (2013). The Analysis of the Guidance and Psychological Counselling Needs of Older People in Terms of Several Variables. Procedia-Social and Behavioral Sciences, 84, 1078-1083. https://doi.org/10.1016/j.sbspro.2013.06.703 
Demirdis, E., \& Celik, S. B. (2013). Older People’s Psychological Counselling and Guidance Needs Scale: Validity and Reliability Study. 3rd World Conference on Psychology, Counselling and Guidance. Procedia-Social and Behavioral Sciences, 84, 652-657. https://doi.org/10.1016/j.sbspro.2013.06.620

Dong, X. Q. (2015). Elder Abuse: Systematic Review and Implications for Practice. Journal of the American Geriatrics Society, 63, 1214-1238. https://doi.org/10.1111/jgs.13454

Egbo, A. C. (2015). The Challenges of Guidance and Counselling Practices as Perceived by Secondary School Counsellors in Enugu State Nigeria. International Journal of Education and Research, 3, 375-384.

Endut, W., \& Ahmad, F. (2009). Prospek Permintaan Terhadap Perkhidmatan Penjagaan Warga Tua. Prosiding Perkembangan IV, 1, 337-353.

Esther, E., Shahrul, K., \& Low, W. Y. (2006). Elder Abuse: A Silent Cry. The Malaysian Journal of Psychiatry, 14, 29-34.

Foster, T. W., Kreider, V., \& Waugh, J. (2009). Counselling Students' Interest in Gerocounselling: A Survey Study. Gerontology \& Geriatrics Education, 30, 226-242. https://doi.org/10.1080/02701960903133489

Fullen, M. C. (2018). Ageism and the Counselling Profession: Causes, Consequences, and Methods for Counteraction. The Professional Counsellor, 8, 104-114. https://doi.org/10.15241/mcf.8.2.104

Hammond, M., \& Wellington, J. (2013). Research Methods. The Key Concepts. Abingdon: Routledge. https://doi.org/10.4324/9780203097625

Hepple, J. (2004). Psychotherapies with Older People: An Overview. Advances in Psychiatric Treatment, 10, 371-377. http://apt.rcpsych.org/371 https://doi.org/10.1192/apt.10.5.371

Hill, A., \& Brettle, A. (2004). Counselling Older People: A Systematic Review. British Association for Counselling and Psychotherapy.

Ismail, Z., \& Wan Ahmad, W. I. (2006). Warga Tua di Malaysia: Masalah dan Keperluan Kaunseling. Simposium Pembangunan Komuniti Marginal (SIPKOM '06), Petaling Jaya.

Ismail, Z., Ahmad, W. I. W., \& Mahmud, Z. (2007). Gaya Hidup Warga Tua di Malaysia dan Keperluan Kaunseling Kelompok. Jurnal Pengajian Sosial, 10, 1-15.

Jamaluddin, S. Z., Chuan, G. C., \& Abu Taher, M. (2017). Protecting the Elderly against Abuse and Neglect. Legal and Social Strategies. Kuala Lumpur: Universiti Malaya Publication.

Jemain, A. A., Mohamad, L. Z., \& Mohamed, W. N. (2001). Kesejahteraan Hidup di Hari Tua. In Abdul Aziz Jemain, Jaminan Sosial Warga Tua (pp. 1-8). Selangor: Prentice Hall.

Kil, T., Yoon, K., Ryu, H., \& Kim, M. (2019). Effect of Group Integrated Intervention Program Combined Animal-Assisted Therapy and Integrated Elderly Play Therapy on Live Alone Elderly. Journal of Animal Science and Technology, 61, 379-387. https://doi.org/10.5187/jast.2019.61.6.379

Lloyd, A., \& Hashim, A. (1987). Kaunseling dan Bimbingan di Malaysia. Kuala Lumpur: Dewan Bahasa dan Pustaka.

Malaysia Counsellors Act (1998). Laws of Malaysia (Incorporating All Amendments Up to 1 January 2006). The Commissioner of Law Revision, Malaysia: Percetaan Nasional Malaysia BHD.

Malaysia Department of Higher Education, Ministry of Higher Education (2011). Hala Tuju Bidang Kaunseling di Malaysia. Serdang: Penerbit Universiti Putra Malaysia.

Manaf, A. R. A. (2002). Elemen KerjaSosial: Satu Tinjauan Umum. In A. R. A. Manaf, \& 
Z. Jamaluddin (Eds.), Kerja Sosial: Artikel-artikel Pilihan (pp. 1-19). Kuala Lumpur: Utusan Publications \& Distributors.

Mansor, M., Ismail, N., Ghazali, S. S., Hamid, T. A., \& Noor, A. M. (2019). Knowledge, Attitude and Practice on Elder Maltreatment among Staff in the Aged Care Institution. Pertanika Journal of Social Sciences \& Humanities, 27, 89-107.

Mohd Yusoff, J. Z. (2009). Jenayah Dalam Keluarga: Penderaan Dan Pengabaian Warga Tua Di Malaysia. Surabaya: International Conference on Corporate Law (ICCL).

Mohd Yusoff, J. Z. (2010). Jenayah keganasan rumah tangga. Kuala Lumpur: Penerbit Universiti Malaya.

Moleong, L. (2002). Metodologi Penelitian Kualitatif. Bandung: PT. Remaja Rosdak arya.

Mushaandja, J., Haihambo, C., Vergnani, T., \& Frank, E. (2013). Major Challenges Facing Teacher Counsellors in Schools in Namibia. Educational Journal, 2, 77-83.

https://doi.org/10.11648/j.edu.20130203.13

Nawi, N. H., Ahmad, P. H. M., Malek, M. D. A., Cosmas, G., Ibrahim, H., Voo, P., \& Kiyah, W. (2016). Intergenerasi, Sokongan Psikologi dan Sosial Penjagaan Warga emas dalam Pelbagai Etnik di Sabah. Southeast Asia Psychology Journal, 4, 24-34.

Nikumaa, H., \& Leinonen, A. (2019). Counselling of People with Dementia in Legal Matters-Social and Health Care Professionals Role. European Journal of Social Work, 23, 685-698. https://doi.org/10.1080/13691457.2019.1568970

Nyamwange, C. B., Nyakan, P. O., \& Ondima, P. C. (2012). Assessment of Challenges Facing Secondary School Guidance and Counselling Teachers in Nyamira District, Kenya. Journal of Education and Practice, 3, 41-47.

Ogedegbe, G., Fernandez, S., Fournier, L., Silver, S. A., Kong, J., Gallagher, S., Calle, F., Plumhoff, J., Sethi, S., Choudhury, E., \& Teresi, J. A. (2013). The Counselling Older Adults to Control Hypertension (COACH) Trial: Design and Methodology of a GroupBased Lifestyle Intervention for Hypertensive Minority Older Adults. Contemporary Clinical Trials, 35, 70-79. https://doi.org/10.1016/j.cct.2013.02.008

Pakkala, I., Read, S., Leinonen, R., Hirvensalo, M., Lintunen, T., \& Rantanen, T. (2008). The Effects of Physical Activity Counselling on Mood among 75- to 81-Year-Old People: A Randomized Controlled Trial. Preventive Medicine, 46, 412-418. https://doi.org/10.1016/j.ypmed.2007.11.002

Patton, Q. M. (1990). Qualitative Evaluation and Research Methods (2nd ed.). London: Sage Publications Inc.

Rantanen, T., Hassandra, M., Pynnonen, K., Siltanen, S., Kokko, K., Karavirta, L., Kauppinen, M., Sipila, S., Saajanaho, M., \& Portegijs, E. (2020). The Effect of Individualized, Theory-Based Counselling Intervention on Active Aging and Quality of Life among Older People (the AGNES Intervention Study). Aging Clinical and Experimental Research, 32, 2081-2090. https://doi.org/10.1007/s40520-020-01535-x

Rantanen, T., Pynnonen, K., Saajanaho, M., Siltanen, S., Karavirta, L., Kokko, K., Karvonen, A., Kauppinen, M., Rantalainen, T., Rantakokko, M., Portegijs, E., \& Hassandra, M. (2019). Individualized Counselling for Active Aging: Protocol of a Single-Blinded, Randomized Controlled Trial among Older People (the AGNES Intervention Study). BMC Geriatrics, 19, 5. https://doi.org/10.1186/s12877-018-1012-Z

Royse, D., Thyer, B. A., Padgett, D. K., \& Logan, T. K. (2001). Program Evaluation an Introduction (3rd ed.). Belmont, CA: Brooks/Cole.

Rozaino, N. D. D. A., \& Fuad Mohd Kari, D. N. (2018). Keperluan Perkhidmatan Kaunseling dalam Kalangan Warga Emas. Asean Psychology \& Couselling Conference, Kuala Lumpur, 26-27 September 2018. 
Salleh, M. F. M. (2016). Ageing in an Inclusive Society: Social Support System for Older Persons in Malaysia. Anjuran Kerjasama Jabatan Kebajikan Masyarakat Malaysia dan Japan International Cooperation, Kuala Lumpur, 12-13 October 2016.

Seidel, J. V. (1998). Qualitative Data Analysis. Originally Published as Qualitative Data Analysis, in the Ethnograph v5.0: A Users Guide, Appendix E, 1998, Colorado.

Sharif, N. C., Alavi, K., \& Subramaniam, P. (2019). Hubungan antara kebimbangan dan kemurungan dengan kualiti hidup warga emas demensia: Keperluan terapi kenangan berkelompok di institusi penjagaan. Universiti Malaysia Terengganu Journal of Undergraduate Research, 1, 95-104.

Sharif, N. C., Alavi, K., Subramaniam, P., \& Zamani, Z. A. (2015). Pengalaman dan faktor pengabaian warga emas dalam komuniti. Journal e-Bangi, 10, 118-134.

Talha, R. (2015). Ciri-Ciri Demografi Utama Penduduk. Kertas Kerja Persidangan Meja Bulat Realiti Masyarakat Menua: Punca dan Cabarannya Di Malaysia. Kuala Lumpur: Anjuran Institut Kefahaman Islam Malaysia. Dewan Besar IKIM.

Talib, J. (2009). Profesionalisme Kaunselor Sekolah Rendah. Malim Bil. 10. Bangi: Universiti Kebangsaan Malaysia.

Tanaka, H., Hashimoto, M., Fukuhara, R., Ishikawa, T., Yatabe, Y., Kaneda, K., \& Ikeda, M. (2015). Relationship between Dementia Severity and Behavioural and Psychological Symptoms in Early-Onset Alzheimer's Disease. Psychogeriatrics: The Official Journal of the Japanese Psychogeriatric Society, 15, 242-247.

https://doi.org/10.1111/psyg.12108

Tay, K. W., Subramaniam, P., \& Oei, T. P. (2018). Cognitive Behavioural Therapy Can Be Effective in Treating Anxiety and Depression in Persons with Dementia: A Systematic Review. Psychogeriatrics, 19, 264-275. https://doi.org/10.1111/psyg.12391

Toner, M. A., \& Shadden, B. B. (2002). Counselling Challenges: Working with Older Clients and Caregivers. Contemporary Issues in Communication Science and Disorders, 29, 6878. https://doi.org/10.1044/cicsd 29 S 68

Visser, A. (2000). Chronic Diseases, Aging, and Dementia: Implications for Patient Education and Counselling (Book Reviews). Patient Education and Counselling, 39, $293-$ 309. https://doi.org/10.1016/S0738-3991(99)00002-6

Wan Ahmad, W. I., Redzuan, M., Emby, Z., \& Hamid, A. H. (2009). Kesejahteraan subjektif warga tua di Malaysia: Kes warga tua desa Kelantan. International Journal of Management Studies, 16, 63-96. https://doi.org/10.32890/ijms.16.2.2009.9971

Yin, R. K. (1994). Second Edition Case Study Research: Design and Method. Thousand Oaks, CA: Sage Publications. 